\title{
Physiological Growth and Yield of Two Groundnut Varieties as Influenced by Light and Boron
}

\author{
Md. QUAMRUZZAMAN ${ }^{1 *}$, Md. Jafar ULLAH ${ }^{1}$, Md. Fazlul KARIM ${ }^{1}$, \\ Nazrul ISLAM ${ }^{2}$, Md. Jahedur RAHMAN ${ }^{2}$, Md. Dulal SARKAR ${ }^{2}$
}

${ }^{1}$ Sher-e-Bangla Agriculture University, Department of Agronomy, Dhaka-1207, Bangladesh; bdquamu@gmail.com ( ${ }^{*}$ corresponding author) ${ }^{2}$ Sher-e-Bangla Agriculture University, Department of Horticulture, Dhaka-1207, Bangladesh

\begin{abstract}
Light and boron play a significant role in the physiological growth and yield of crops such as groundnut. Even so, there has been little information on the application of boron in groundnut, while no information is available in Bangladesh regarding the imposition of light in groundnut. Therefore, two field experiments were conducted in order to evaluate the physiological growth and seed yield of groundnut. Treatments included two levels of light, viz., $\mathrm{L}_{0}=$ normal day length $(\approx 12-\mathrm{h}$ light $)$ and $\mathrm{L}$ $=$ normal day length +6 -h extended light at night $(\approx 18-\mathrm{h}$ light $)$; three levels of boron, viz., $0-\mathrm{kg} \mathrm{B} \mathrm{ha}^{-1}\left(\mathrm{~B}_{0}\right), 1-\mathrm{kg} \mathrm{B} \mathrm{ha-}^{-1}\left(\mathrm{~B}_{1}\right)$ and 2-kg B ha' ${ }^{-1}\left(B_{2}\right)$, and two groundnut varieties, viz., $\mathrm{V}_{1}=$ 'Dhaka-1' and $\mathrm{V}_{2}=$ 'BARI Chinabadam-8'. The results obtained from the experiment revealed that the highest LAI, LAR, LMR and RWR were recorded in $L, B_{2}$ and $V_{2}$ variants, while NAR was the highest in $\mathrm{L}_{0}$ and $\mathrm{B}_{0}$. Moreover, it was noted an inconsistent result for RGR found for boron application. Based on the results, it could be concluded that boron is one of the factors responsible for higher yield of groundnut; nevertheless, under the extended light, it is not possible to get the highest yield.
\end{abstract}

Keywords: boron, light, micronutrient, yield, groundnut, physiological growth, peanut

\section{Introduction}

Groundnut (Arachis hypogaea L.) is one of the major and crucial oilseed crop, as well as protein rich crop, in the world (Onemli, 2012), while boron is an important micronutrient that is essential for healthy growth and development of groundnut (Gascho and Davis, 1995). This micronutrient played a vital role in the different physiological functions and process of plants (Mengel and Kirkby, 1982). As a result, application of boron facilitated the vegetative growth and reproductive development of groundnut. A slight quantity of boron is required by plants (El-Wahab and Mohamed, 2008) but the application of this element in crops was limited in farmer's field (Nasreen $e$ al., 2015). As a result, this nutrient was rapidly becoming deficient in soils (Tahir et al., 2009) and the boron deficiency problem had been identified in Bangladesh (Ahmed and Hossain, 1997). Therefore, more research was needed to find out the effect of the application of boron in the soil of Bangladesh. So, it was a principal issue to investigate the response of boron on physiological growth as well as the yield of groundnut.

Light also solely played a crucial role in the physiological process and reproductive development of legume crops, like groundnut. The three most important characteristics of light (quantity, quality and direction) were perceived by different photosensory systems of the plant that collectively regulate the plant development (Hangarter, 1997). Imposition of light positively influenced on the vegetative growth, but reduced the yield of groundnut (Nigam et al., 1998; Bagnall and King, 1991; Quamruzzaman et al., 2016a). It was noted with specific evidence that excessive light stress can lead to antioxidant enzymes activation as well as ROS (Reactive Oxygen Species) accumulation in the plant (Mittler, 2002).

Never the less, no light experiment was conducted in Bangladesh to evaluate the effect of artificial light on physiological growth as well as yield of groundnut. As for why the present study was carried out, in order to determine the exact duration of light and the optimum boron levels for an improved physiological growth and yield of groundnut.

\section{Materials and Methods}

\section{Experimental site}

Two trial experiments were conducted at the Central Experimental Farm, Sher-e-Bangla Agricultural University, Dhaka-1207, Bangladesh. The first trial duration was between 17th March to 10th July 2014 and the second trial 
duration was between 15th March until 08th July 2015, respectively. Both experiments were conducted in the same field and soil samples of the experimental field werew analyzed in the laboratory of Soil Resource Development Institute (SRDI) before the experiment set up (Table 1). The experimental field was located at the Madhupur Tract, which is the name of the Agro-ecological Zone "AEZ-28" (BBS 2014-15). The average air temperature, relative humidity and rainfall of the two cropping seasons (2014 \& 2015 cropping season) of the experimental site were also recorded (Table 2).

\section{Field operations}

Cultivars 'Dhaka-1' (Maizchor Badam) and 'BARI Chinabadam- 8 ' were used for the experiment. Seeds were provided by BARI (Bangladesh Agricultural Research Institute), Gazipur. Along with boron (source: Boric Acid), the recommended doses of organic and inorganic fertilizer were incorporated with soil during final land preparation. Cowdung, urea, triple superphosphate, muriate of potash, gypsum and zinc sulphate were applied at $10 \mathrm{t} \mathrm{ha}^{-1}, 25 \mathrm{~kg} \mathrm{ha}$ , $160 \mathrm{~kg} \mathrm{ha}^{-1}, 75 \mathrm{~kg} \mathrm{ha}^{-1}, 170 \mathrm{~kg} \mathrm{ha}^{-1}$ and $4 \mathrm{~kg} \mathrm{ha}^{-1}$, respectively.

\section{Experimental design and treatment details}

Both of the experiments were laid out in a $2 \times 3 \times 2$ factorial design with three replications. Spacing was maintained $30 \mathrm{~cm} \times 15 \mathrm{~cm}$ and seed rate was of $110 \mathrm{~kg}$ seeds $\mathrm{ha}^{-1}$ (with shell). The first factor was duration of light, e.g., normal day length $+6^{\text {h }}$ extended light at night $(\approx 18-\mathrm{h}$ light) (L) and normal day length ( $\approx 12$-h light) $\left(\mathrm{L}_{0}\right)$; the second factor was represented by the three levels of boron (source: Boric Acid) viz., $0 \mathrm{~kg} \mathrm{~B} \mathrm{ha}^{-1}(\mathrm{~B} 0), 1 \mathrm{~kg} \mathrm{~B} \mathrm{ha}^{-1}\left(\mathrm{~B}_{1}\right)$ and $2 \mathrm{~kg} \mathrm{~B} \mathrm{ha}{ }^{-1}\left(B_{2}\right)$; the third factor was represented by two

Table 1. Composition of soil elements of the experimental field

\begin{tabular}{cc}
\hline Element & Levels in the soil plot \\
\hline $\mathrm{pH}$ & 5.9 \\
$\mathrm{~N}$ & $0.071 \%$ \\
$\mathrm{~K}$ & $0.31 \mathrm{meq} / 100 \mathrm{~g}$ soil \\
$\mathrm{Ca}$ & $6.36 \mathrm{meq} / 100 \mathrm{~g}$ soil \\
$\mathrm{P}$ & $14.04 \mu \mathrm{g} / \mathrm{g}$ soil \\
$\mathrm{S}$ & $15.16 \mu \mathrm{g} / \mathrm{g}$ soil \\
$\mathrm{B}$ & $0.30 \mu \mathrm{g} / \mathrm{g}$ soil \\
Sand & $27 \%$ \\
\hline Silt & $43 \%$ \\
Clay & $30 \%$ \\
Organic matter & $0.78 \%$ \\
\hline N=Total nitrogen, K=Exchangeable potassium, Ca= Exchangeable calcium, P= \\
Exchangeable Phosphorous, S=Exchangeable Sulphur, B=Available boron
\end{tabular}

groundnut varieties viz., 'Dhaka-1' (V1) and 'BARI Chinabadam-8' (V2). The artificial lightening was done by fluorescence bulb to ensure the extended day length. This lightening was started after seedling emergence (one month after seed sowing) from 18:00 h 24:00 h at 30-50,000 lux.

\section{Data collection}

Data were collected on physiological parameters viz., leaf area index (LAI), leaf area ratio (LAR), leaf mass ratio (LMR), root weight ratio (RWR), relative growth rate (RGR), net assimilation rate (NAR) and yield contributing characters viz., seed yield and harvest index (HI). The parameters were measured as described below:

$\mathrm{LAI}=\mathrm{LA} / \mathrm{GA}$

Where, LAI = leaf area index, LA = Leaf area $\left(\mathrm{cm}^{2}\right), \mathrm{GA}$ $=$ ground area $\left(\mathrm{cm}^{2}\right)$

LAR $=$ LA/PDW

Where, LAR = leaf area ratio, LA $=$ Leaf area $\left(\mathrm{cm}^{2}\right)$, $\mathrm{PDW}=$ plant dry weight $(\mathrm{g})$.

$\mathrm{LMR}=\mathrm{LDW} / \mathrm{PDW}$ (g).

Where, $\mathrm{LMR}=$ leaf mass ratio, $\mathrm{LDW}=$ leaf dry weight

\section{$\mathrm{RWR}=\mathrm{RDW} / \mathrm{PDW}$}

Where, RWR = root weight ratio, RDW = root dry weight $(\mathrm{g})$.

$\mathrm{RGR}=\left(\operatorname{lnPDW} \mathrm{L}_{-}-\ln \mathrm{PDW} \_2\right) /\left(\left(\mathrm{t} \_2-\mathrm{t} \_1\right)\right)$

Where, $t=$ time. Subscripts 1 and 2 refer to the initial and sampling dates (days), respectively.

\section{$\mathrm{NAR}=\mathrm{RGR} / \mathrm{LAR}$}

$\mathrm{HI}=($ Economic yield $) /($ Biological yield $)$

Where Economic yield (pod yield) biological yield were measured as tha-1

\section{Statistical analysis}

Data collected in two cropping seasons (2014 and 2015) were mean together on account of the non-significant interaction. Then one-way ANOVA (analysis of variance) of means data of two trial experiments was analyzed by using IBM SPSS (Version 20.0) and mean separation was done at $P \leq 0.05$ by using Tukey's test (Tukey, 1977).

\section{Results and Discussion}

\section{Leaf area index (LAI)}

Leaf area index varied significantly by different light treatment (Table 3). Results revealed that LAI increased in $\mathrm{L}$ compared to $\mathrm{L}_{0}$. Data showed that the LAI ranged from $6.13\left(\mathrm{~L}_{0}\right)$ to $9.41\left(\mathrm{~L}_{1}\right)$. Higher LAI is one of the most important criteria that help to produce higher metabolites of plants. Increased LAI has been found to increase the capability of the plants to intercept more light (Prieto et al.,

Table 2. Monthly record of air temperature, relative humidity and rainfall of the experimental site during the period of March to July 2014 and 2015 (Mean of two years)

\begin{tabular}{|c|c|c|c|c|c|}
\hline \multirow{2}{*}{ Month } & \multicolumn{2}{|c|}{ Air temperature $\left({ }^{\circ} \mathrm{C}\right)$} & \multicolumn{2}{|c|}{ Relative humidity (\%) } & \multirow{2}{*}{$\begin{array}{c}\text { Rainfall (mm) } \\
\text { (total) }\end{array}$} \\
\hline & Maximum & Minimum & Maximum & Minimum & \\
\hline March & 37.4 & 20.2 & 80.2 & 32.4 & 3.80 \\
\hline April & 39.4 & 19.4 & 80.2 & 39.2 & 65.60 \\
\hline May & 38.2 & 19.3 & 89.2 & 40 & 202 \\
\hline June & 37.2 & 17.4 & 88.4 & 46.3 & 282.7 \\
\hline July & 35.6 & 18.2 & 88.2 & 55.4 & 107.8 \\
\hline
\end{tabular}

Source: Sher-e-Bangla Agricultural University mini weather station, Dhaka-1207, Bangladesh 
2007). The highest LAI was found due to the supplementation of $\mathrm{L}$ that may have the ability to produce higher metabolites in groundnut.

Leaf area index was increased significantly up to 90 DAP and then decreased at harvest in boron application area (Table 3). Due to different doses of boron, the variation of LAI was observed, and it ranged from $0.64\left(\mathrm{~B}_{0}\right)$ to 10.74 $\left(B_{2}\right)$. Probably, application of boron increased the vegetative growth of plant up to the certain period and then started to work on the reproductive unit. It had evidence that the application of boron increased the vegetative growth and yield of groundnut (Singaravel et al., 2006; Kabir et al., 2013), which is in consequence of the increased LAI and the resultant increased light interception (Prieto et al., 2007). The higher LAI was found due to the application of $\mathrm{B} 2$ that may have the ability to produce higher metabolites in groundnut. Geethanjali et al. (2015) stated that application of boron increased the leaf area and LAI of groundnut.

\section{Leaf area ratio (LAR)}

Table 3 showed that the highest leaf area ratio was recorded from $\mathrm{L}_{0}$ at $60 \mathrm{DAP}\left(276.97 \mathrm{~cm}^{2} \mathrm{~g}^{-1}\right)$ and 90 DAP $\left(139.98 \mathrm{~cm}^{2} \mathrm{~g}^{-1}\right)$, but at harvest the highest LAR was found from $\mathrm{L}\left(82.29 \mathrm{~cm}^{2} \mathrm{~g}^{-1}\right)$. Variation in LAR due to the imposition of light produced the highest leaf area and plant dry weight compared with control at 60 DAP and 90 DAP. It was observed that leaf shedding started after 90 DAP and got the maximum at harvest in L treatment area. Probably this leaf shedding was responsible for the highest LAR in light treatment plots. Therefore, it can be concluded that the supplementation of light facilitated vegetative growth (Ketring, 1979), as given by the results with the highest leaf area and plant dry weight as well as LAR.

Due to the application of boron, the highest LAR was recorded from boron at $1-\mathrm{kg} \mathrm{ha}^{-1}$ at all sampling dates and the lowest were from control treatment (Table 3). Data also represented that LAR is showing an increasing trend up to $60 \mathrm{DAP}$ and then started to gradual decrease up to the harvest, because boron was responsible for the vegetative growth of groundnut plant (Kabir, 2013). Harris and Brolmann (1996) also reported that plant dry weight increased with the application of boron in groundnut. The addition of $\mathrm{B}$ was also responsible for the leaf expansion of groundnut (Dell and Huang, 1997). Thus, a higher value of LAR was found in boron application area.

\section{Leaf mass ratio (LMR)}

For the supplementation of additional light, the leaf mass ratio showed variation result at all sampling dates (Table 4). The highest LMR was recorded as $0.875 \mathrm{gg}^{-1}$ and the lowest as $0.280 \mathrm{~g} \mathrm{~g}^{-1}$. Though, the light was responsible for the highest plant dry weight (Ketring, 1979) and leaf dry weight (Acock et al., 1996), it did not produce the highest LMR at 60 DAP. Data showed that light treatment produced maximum LMR at $90 \mathrm{DAP}$ and at harvest. Probably, at 60 DAP plants did not get enough light to produce high LMR, where as in the present study light was imposed just after $30 \mathrm{DAP}$.

Boron at $2 \mathrm{~kg} \mathrm{ha}^{-1}$ produced significantly $(p \leq 0.001)$ higher LMR at all growth stage (Table 4) where the lowest LMR was found from control treatment. The highest number of leaf, plant dry weight and leaf dry weight, as well as LMR, were recorded from boron at $2-\mathrm{kg} \mathrm{ha}^{-1}$. It was reported that vegetative growth, as well as plant dry weight of groundnut, were the highest for application of boron (Kabir et al., 2013). So, the fact that LMR was significantly higher for the application of boron. Prieto et al. (2007) stated that increased LMR gave a higher capability of the plants to intercept more light. The highest LMR was found due to the application of $B_{2}$ that may have the highest capability to produce more elevated metabolites in groundnut.

\section{Root weight ratio (RWR)}

Root weight ratio differed significantly due to the imposition of light (Table 4). The highest RWR was found at harvest in $\mathrm{L}\left(0.080 \mathrm{~g} \mathrm{~g}^{-1}\right)$ and the lowest at 90 DAP in L0 $\left(0.045 \mathrm{~g} \mathrm{~g}^{-1}\right)$. The RWR showed a decreasing trend up to 90 DAP, but at harvest it suddenly increased for both treatments. This might be due to leaf shedding, since leaf shedding started after $90 \mathrm{DAP}$ and it was maximum at

Table 3. Effect of light and boron on leaf area index and leaf area ratio of two groundnut varieties (mean of two trails)

\begin{tabular}{|c|c|c|c|c|c|c|c|c|}
\hline \multirow{2}{*}{ Treatment } & \multicolumn{4}{|c|}{ LAI } & \multicolumn{4}{|c|}{$\operatorname{LAR}\left(\mathrm{cm}^{2} \mathrm{~g}^{-1}\right)$} \\
\hline & $30 \mathrm{DAP}$ & $60 \mathrm{DAP}$ & $90 \mathrm{DAP}$ & Harvest & $30 \mathrm{DAP}$ & 60 DAP & $90 \mathrm{DAP}$ & Harvest \\
\hline \multicolumn{9}{|c|}{ Light (L) } \\
\hline $\mathrm{L}$ & - & 6.39 & 9.41 & 8.24 & - & 212.88 & 135.76 & 82.29 \\
\hline $\mathrm{L}_{0}$ & - & 6.13 & 8.78 & 6.91 & - & 276.97 & 139.98 & 74.85 \\
\hline \multicolumn{9}{|c|}{ Boron $(\mathrm{B})$} \\
\hline $\mathrm{B}_{0}$ & 0.64 & 5.06 & 6.19 & 6.55 & 162.922 & 216.513 & 160.705 & 70.927 \\
\hline $\mathrm{B}_{1}$ & 1.06 & 6.65 & 10.37 & 7.98 & 230.382 & 267.873 & 155.804 & 84.358 \\
\hline $\mathrm{B}_{2}$ & 1.11 & 7.08 & 10.74 & 8.29 & 200.471 & 250.384 & 151.092 & 80.426 \\
\hline & & & & Variety & & & & \\
\hline $\mathrm{V}_{1}$ & 0.824 & 5.08 & 7.32 & 7.01 & 221.001 & 240.351 & 117.025 & 90.024 \\
\hline $\mathrm{V}_{2}$ & 1.051 & 7.44 & 10.87 & 8.14 & 174.849 & 249.025 & 158.709 & 67.116 \\
\hline \multicolumn{9}{|c|}{ Significance $(P)$ at $5 \%$} \\
\hline $\mathrm{L}$ & - & 0.002 & $<0.001$ & $<0.001$ & -- & $<0.001$ & 0.007 & $<0.001$ \\
\hline B & $<0.001$ & $<0.001$ & $<0.001$ & $<0.001$ & $<0.001$ & $<0.001$ & $<0.001$ & $<0.001$ \\
\hline $\mathrm{V}$ & $<0.001$ & $<0.001$ & $<0.001$ & $<0.001$ & $<0.001$ & 0.054 & $<0.001$ & $<0.001$ \\
\hline $\mathrm{L} \times \mathrm{B}$ & - & 0.002 & 0.148 & 0.931 & - & 0.094 & 0.045 & 0.238 \\
\hline $\mathrm{L} \times \mathrm{V}$ & - & 0.169 & $<0.001$ & 0.338 & - & 0.019 & 0.005 & 0.016 \\
\hline $\mathrm{B} \times \mathrm{V}$ & $<0.001$ & $<0.001$ & $<0.001$ & $<0.001$ & 0.064 & $<0.001$ & 0.077 & $<0.001$ \\
\hline $\mathrm{L} \times \mathrm{B} \times \mathrm{V}$ & - & 0.009 & $<0.001$ & 0.308 & - & 0.001 & $<0.001$ & 0.747 \\
\hline
\end{tabular}

$\mathrm{DAP}=$ Day After Planting, $\mathrm{B}=$ Boron; $\mathrm{L}=$ light; $\mathrm{V}=$ Variety; $\mathrm{P}=$ Probability. Means were separated by Tukey's test at $\mathrm{P} \leq 0.05, \mathrm{~B}_{0}=0 \mathrm{Kg} \mathrm{B}$ ha ${ }^{-1}(\mathrm{Control}), \mathrm{B}_{1}=1 \mathrm{Kg} \mathrm{B}$ ha ${ }^{-1}$, $\mathrm{B}_{2}=2 \mathrm{Kg} \mathrm{B} \mathrm{ha}^{-1}, \mathrm{~L}=$ normal day light +6 -h extended light at night $(\approx 18$-h light $), \mathrm{L} 0=$ normal day light $(\approx 12$-h light $), \mathrm{V}_{1}=$ 'Dhaka-1', $\mathrm{V}_{2}=$ ' $\mathrm{BARI} \mathrm{Chinabadam}-8$ ' 
harvest. Even so, root dry weight was almost the same as 90 DAP data. The longer roots, as well as the highest root weight, might be responsible for the highest nutrient uptake from soil. And the highest RWR could be responsible for the highest vegetative growth of plants, as concluded by Nigam et al., 1994, who noted that light facilitated the highest vegetative growth in peanut plants.

Root weight ratio was significant in boron application area (Table 4). The highest significant RWR was recorded from 2-kg boron ha ${ }^{-1}$ at all sampling dates $\left(0.198 \mathrm{~g} \mathrm{~g}^{-1}, 0.089\right.$ $\mathrm{g} \mathrm{g}^{-1}, 0.063 \mathrm{~g} \mathrm{~g}^{-1}$ and $0.083 \mathrm{~g} \mathrm{~g}^{-1}$, respectively). Harris and Brolman (1966) stated that due to the application of boron root weight increased and Kabir et al. (2013) found that groundnut plants' dry weight was highest for boron fertilization. Therefore, RWR in the present study might also be the highest for the application of boron.

\section{Relative growth rate ( $R G R$ )}

The relative growth rate was the highest at $60 \mathrm{DAP}$ in $\mathrm{L}$, but the rest of sampling dates it was highest in $\mathrm{L}_{0}(5)$. Due to the light treatment, the significantly decline trend of RGR towards physiological maturity could be a result of leaf shedding. There is also evidence that the upper leaves when in dense condition caused shedding effect on the lower leaves reducing the photosynthetic capability and imposing them to more pest attack (Banik et al., 2009).

Boron produced inconsistent, but significant, relative growth rate at all growth stage (Table 5). The highest plant dry weight was found from boron at $2-\mathrm{kg} \mathrm{ha}^{-1}$, but in the case of RGR it was not consistent among the boron treatments, because initial plants dry weight was not similar for different treatments. Cikili et al. (2015) found that application of boron increased plant growth and biomass production up to a certain growth stage, but when more boron doses were applied soil toxicity occurred, that reduced plant growth and biomass production. In the current study, it was not observed boron toxicity effect. Since plant dry weight was significantly higher for the addition of boron, RGR also might be significant for boron application. RGR was not showing the similar trend as others parameter studied hereby, as why further study is continuing to find out the inconsistent result of RGR.

\section{Net assimilation rate (NAR)}

Net assimilation rate was found with a significantly increasing trend up to 90 DAP due to light treatment (Table 5). The highest NAR was recorded from light treatment compared with control treatment, at $60 \mathrm{DAP}$ and 90 DAP, but at harvest, it showed a decreasing trend. The decreased trends of net assimilation rate in groundnut may be due to mutual shading at physiological maturity stage of plants, which affects the lower leaves and thus reduce the photosynthetic capability of the older leaves (Banik et al., 2009). This mutual shading is also responsible for pest attack that reduced leaf area of groundnut (Banik et al., 2009). Data revealed that light helped to produce the highest vegetative unit in a plant that was most relevant to higher NAR. Quamruzzaman et al. (2016a) reported that light helped to produce the highest vegetative growth, thus the current data consisted with their finding.

Although at 30 DAP the highest NAR was recorded from $2-\mathrm{kg} \mathrm{ha}^{-1}$ boron application area, at the rest of sampling dates control treatment produced the highest NAR (Table 5). It had evidence that shading reduced the NAR, but had

Table 4. Effect of light and boron on leaf mass ratio and root weight ratio of two groundnut varieties (Mean of two trails)

\begin{tabular}{|c|c|c|c|c|c|c|c|c|}
\hline \multirow{2}{*}{ Treatment } & \multicolumn{4}{|c|}{$\operatorname{LMR}\left(\mathrm{g} \mathrm{g}^{-1}\right)$} & \multicolumn{4}{|c|}{ RWR $\left(\mathrm{g} \mathrm{g}^{-1}\right)$} \\
\hline & $30 \mathrm{DAP}$ & 60 DAP & $90 \mathrm{DAP}$ & Harvest & $30 \mathrm{DAP}$ & $60 \mathrm{DAP}$ & $90 \mathrm{DAP}$ & Harvest \\
\hline \multicolumn{9}{|c|}{ Light (L) } \\
\hline $\mathrm{L}$ & - & 0.759 & 0.472 & 0.331 & - & 0.074 & 0.059 & 0.080 \\
\hline $\mathrm{L}_{0}$ & - & 0.875 & 0.445 & 0.280 & - & 0.067 & 0.045 & 0.063 \\
\hline \multicolumn{9}{|c|}{ Boron (B) } \\
\hline $\mathrm{B}_{0}$ & 1.703 & 0.757 & 0.366 & 0.275 & 0.161 & 0.053 & 0.043 & 0.060 \\
\hline $\mathrm{B}_{1}$ & 2.019 & 0.810 & 0.457 & 0.308 & 0.168 & 0.069 & 0.049 & 0.075 \\
\hline $\mathrm{B}_{2}$ & 2.507 & 0.885 & 0.557 & 0.333 & 0.198 & 0.089 & 0.063 & 0.083 \\
\hline \multicolumn{9}{|c|}{ Variety $(V)$} \\
\hline $\mathrm{V}_{1}$ & 2.410 & 0.881 & 0.402 & 0.344 & 0.179 & 0.075 & 0.0524 & 0.080 \\
\hline $\mathrm{V}_{2}$ & 1.743 & 0.752 & 0.515 & 0.266 & 0.172 & 0.065 & 0.0519 & 0.063 \\
\hline \multicolumn{9}{|c|}{ Significance $(\mathrm{P})$ at $5 \%$} \\
\hline $\mathrm{L}$ & - & $<0.001$ & $<0.001$ & $<0.001$ & - & 0.030 & $<0.001$ & $<0.001$ \\
\hline B & $<0.001$ & $<0.001$ & $<0.001$ & $<0.001$ & 0.012 & $<0.001$ & $<0.001$ & $<0.001$ \\
\hline $\mathrm{V}$ & $<0.001$ & $<0.001$ & $<0.001$ & $<0.001$ & 0.447 & 0.003 & 0.967 & $<0.001$ \\
\hline $\mathrm{L} \times \mathrm{B}$ & - & 0.308 & $<0.001$ & 0.634 & - & 0.494 & 0.036 & 0.969 \\
\hline $\mathrm{L} \times \mathrm{V}$ & - & 0.002 & $<0.001$ & 0.054 & - & 0.709 & 0.001 & 0.218 \\
\hline$B \times V$ & 0.790 & 0.827 & $<0.001$ & $<0.001$ & 0.098 & 0.835 & 0.030 & 0.004 \\
\hline $\mathrm{L} \times \mathrm{B} \times \mathrm{V}$ & - & 0.001 & 0.700 & 0.008 & - & 0.416 & 0.416 & 0548 \\
\hline
\end{tabular}

$\mathrm{DAP}=$ Day After Planting, $\mathrm{B}=\mathrm{B}$ oron; $\mathrm{L}=$ light; $\mathrm{V}=$ Variety; $\mathrm{P}=$ Probability. Means were separated by Tukey's test at $\mathrm{P} \leq 0.05, \mathrm{~B}_{0}=0 \mathrm{Kg} \mathrm{B}$ ha ${ }^{-1}(\mathrm{Control}), \mathrm{B}_{1}=1 \mathrm{Kg} \mathrm{B}$ ha ${ }^{-1}$, $\mathrm{B}_{2}=2 \mathrm{Kg} \mathrm{B} \mathrm{ha}^{-1}, \mathrm{~L}=$ normal day light +6 -h extended light at night $(\approx 18$-h light $), \mathrm{L}_{0}=$ normal day light $(\approx 12$-h light $), \mathrm{V}_{1}=$ 'Dhaka-1', $\mathrm{V}_{2}=$ 'BARI Chinabadam- 8 '

Table 5. Effect of light and boron on relative growth rate and net assimilation rate of two groundnut varieties (mean of two trails)

\begin{tabular}{|c|c|c|c|c|c|c|c|c|}
\hline \multirow{2}{*}{ Treatment } & \multicolumn{4}{|c|}{$\operatorname{RGR}\left(\mathrm{g} \mathrm{g}^{-1} \mathrm{~d}^{-1}\right)$} & \multicolumn{4}{|c|}{$\operatorname{NAR}\left(\mathrm{g} \mathrm{cm}^{-2} \mathrm{~d}^{-1}\right)$} \\
\hline & 30 DAP & 60 DAP & 90 DAP & Harvest & $30 \mathrm{DAP}$ & $60 \mathrm{DAP}$ & $90 \mathrm{DAP}$ & Harvest \\
\hline \multicolumn{9}{|c|}{ Light (L) } \\
\hline $\mathrm{L}$ & - & 0.099 & 0.035 & 0.006 & - & 0.000470 & 0.000278 & 0.000092 \\
\hline $\mathrm{L}_{0}$ & - & 0.094 & 0.042 & 0.007 & - & 0.000347 & 0.000319 & 0.000103 \\
\hline \multicolumn{9}{|c|}{ Boron (B) } \\
\hline $\mathrm{B}_{0}$ & 0.020 & 0.098 & 0.038 & 0.008 & 0.000143 & 0.000469 & 0.000374 & 0.000116 \\
\hline $\mathrm{B}_{1}$ & 0.024 & 0.097 & 0.039 & 0.005 & 0.000110 & 0.000372 & 0.000262 & 0.000080 \\
\hline $\mathrm{B}_{2}$ & 0.031 & 0.094 & 0.038 & 0.006 & 0.000168 & 0.000384 & 0.000260 & 0.000096 \\
\hline \multicolumn{9}{|c|}{ Variety $(\mathrm{V})$} \\
\hline $\mathrm{V}_{1}$ & 0.017 & 0.098 & 0.043 & 0.001 & 0.000083 & 0.000423 & 0.000379 & 0.000007 \\
\hline $\mathrm{V}_{2}$ & 0.033 & 0.094 & 0.034 & 0.013 & 0.000198 & 0.000394 & 0.000218 & 0.000188 \\
\hline
\end{tabular}




\begin{tabular}{|c|c|c|c|c|c|c|c|c|}
\hline \multicolumn{9}{|c|}{ Significance $(P)$ at $5 \%$} \\
\hline $\mathrm{L}$ & - & 0.001 & $<0.001$ & 0.737 & - & $<0.001$ & $<0.001$ & 0.003 \\
\hline $\mathrm{B}$ & $<0.001$ & 0.016 & $<0.001$ & $<0.001$ & 0.002 & $<0.001$ & $<0.001$ & $<0.001$ \\
\hline $\mathrm{V}$ & $<0.001$ & 0.006 & $<0.001$ & $<0.001$ & $<0.001$ & 0.004 & $<0.001$ & $<0.001$ \\
\hline $\mathrm{L} \times \mathrm{B}$ & - & 0.283 & 0.002 & $<0.001$ & - & 0.001 & 0.734 & $<0.001$ \\
\hline $\mathrm{L} \times \mathrm{V}$ & - & 0.011 & 0.039 & $<0.001$ & - & 0.002 & 1.000 & $<0.001$ \\
\hline $\mathrm{B} \times \mathrm{V}$ & 0.462 & 0.423 & $<0.001$ & 0.202 & 0.096 & 0.005 & $<0.001$ & 0.121 \\
\hline $\mathrm{L} \times \mathrm{B} \times \mathrm{V}$ & - & 0.487 & 0.011 & 0.292 & - & 0.027 & 0.001 & 0.392 \\
\hline
\end{tabular}

$\mathrm{B}_{2}=2 \mathrm{Kg} \mathrm{B} \mathrm{ha}{ }^{-1}, \mathrm{~L}=$ normal day light +6 -h extended light at night $(\approx 18$-h light $), \mathrm{L} 0=$ normal day light $(\approx 12-\mathrm{h}$ light $), \mathrm{V}_{1}=$ 'Dhaka- 1 ', $\mathrm{V}_{2}=$ 'BARI Chinabadam-8'

no effect on yield (Watson and Wilson, 1956) and the highest number of leaves was observed from boron at $2-\mathrm{kg}$ $\mathrm{ha}^{-1}$. The highest leaf area was found from B2 that might be created excessive shading and maximum numbers of new leaves could have the highest shading effect on older leaves. Thus, NAR decreased due to the application of boron, but $B$ probably helped to increase the uptake of nutrients, that ultimately resulted in the highest yield of groundnut (Naiknware et al., 2015). NAR was not showing the similar trend like other parameters investigated, as why further study is continuing to find out the inconsistent result of NAR.

\section{Seed yield $\left(t h a^{-1}\right)$}

Light treatment was responsible for the significant $(p \leq 0.001)$ reduction of seed yield. Data showed that the highest significant seed yield was recorded from control treatment $\left(\mathrm{L}_{0}=1.37 \mathrm{tha}^{-1}\right)$ compared than additional light $\left(\mathrm{L}=1.23 \mathrm{t} \mathrm{ha}^{-1}\right)$ (Fig. 1). So, the 6-hr extended light might be responsible only for vegetative growth and dry matter produced. Probably this limited time light duration was not responsible for better seed yield. Quamruzzaman et al. (2016b) also stated that the low yield of groundnut was found due to the extended light.

Boron was highly responsible for better yield of groundnut and a significant positive seed yield was recorded from application of boron (Fig. 1). The highest groundnut seed yield $\left(1.53 \mathrm{t} \mathrm{ha}^{-1}\right)$ was found from boron at $2-\mathrm{kg} \mathrm{ha}^{-1}$ and the lowest from control. Because boron was highly responsible for the reproductive development of groundnut (Ansari et al., 2013) and highest yield was recorded in boron treatment area. The finding of Naiknaware $e t$ al. (2015) also supported the present finding.

\section{Harvest index (HI)}

Harvest index was significantly influenced by the light treatment. The additional artificial light was sensible for better vegetative growth. As for why supplementation of light produced the lowest $\mathrm{HI}$ (31.75) compared to control (37.457) (Fig. 2). The highest economic yield was found in $\mathrm{L}_{0}$ and the highest biological yield in L. Probably the extended photoperiod limited the reproductive development of groundnut, but increased the vegetative growth (Ketring, 1979). Quamruzzaman et al. (2016a) also reported similar findings.

Boron treatment also caused a significant increasing result of $\mathrm{HI}$. The highest $\mathrm{HI}$ (38.323) was significantly

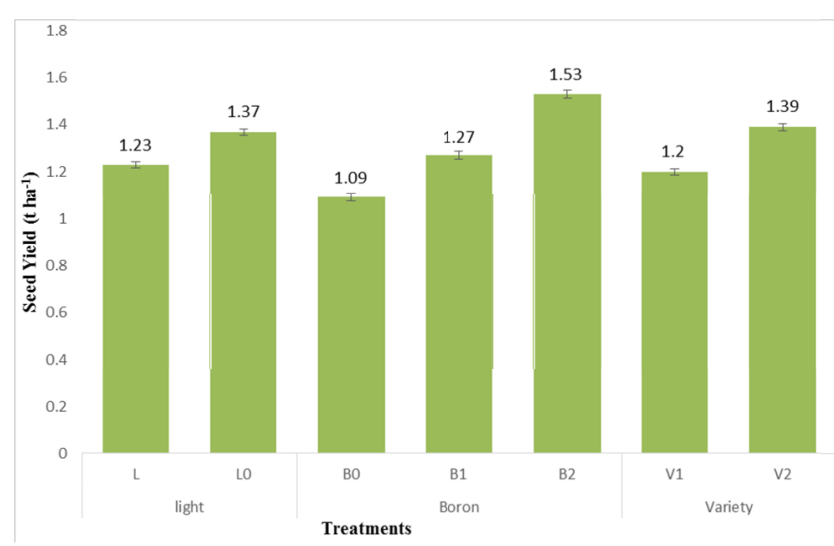

Fig. 1. Effect of boron and light on seed yield $\left(\mathrm{t} \mathrm{ha} \mathrm{a}^{-1}\right)$ of two groundnut varieties

$\mathrm{B}=$ Boron; L=Light; $\mathrm{V}=$ Variety; $\mathrm{B}_{0}=0 \mathrm{~kg} \mathrm{~B} \mathrm{ha}{ }^{-1}, \mathrm{~B}_{1}=1 \mathrm{~kg} \mathrm{~B} \mathrm{ha}{ }^{-1}, \mathrm{~B}_{2}=2 \mathrm{~kg} \mathrm{~B} \mathrm{ha} \mathrm{a}^{-1}$, $\mathrm{L}=$ normal day light +6 -h extended red light at night $(\approx 18$-h light $), \mathrm{L}_{0}=$ normal day light ( $\approx 12$-h light), $V_{1}='$ Dhaka-1', $V_{2}=$ 'BARI Chinabadam-8'. Means were separated by Tukey's test at $\mathrm{P} \leq 0.05$. Vertical bars represent the standard error of the means.

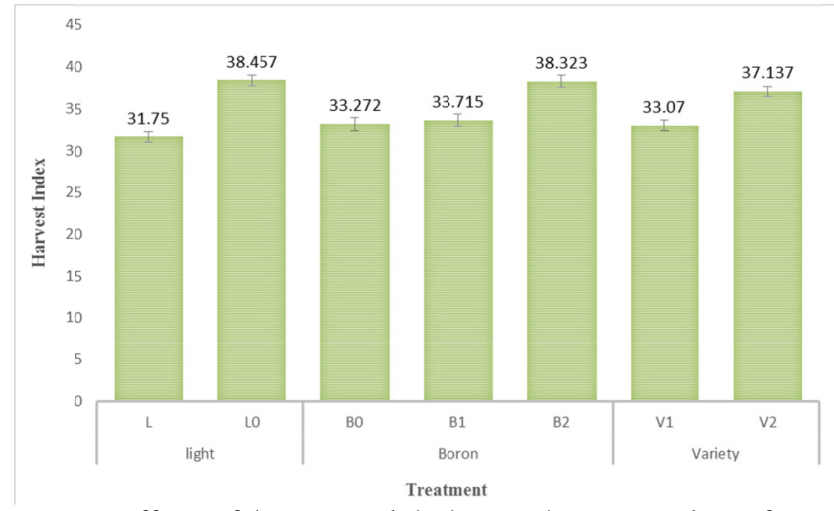

Fig. 2. Effect of boron and light on harvest index of two groundnut varieties

$\mathrm{B}=$ Boron; $\mathrm{L}=$ Light; $\mathrm{V}=$ Variety; $\mathrm{B} 0=0 \mathrm{~kg} \mathrm{~B} \mathrm{ha}{ }^{-1}, \mathrm{~B}_{1}=1 \mathrm{~kg} \mathrm{~B} \mathrm{ha}{ }^{-1}, \mathrm{~B}_{2}=2 \mathrm{~kg} \mathrm{~B} \mathrm{ha}{ }^{-1}$ $\mathrm{L}=$ normal day light +6 -h extended red light at night $(\approx 18$-h light $), \mathrm{L}_{0}=$ normal day light ( $\approx 12$-h light), $V_{1}=$ 'Dhaka-l', $V_{2}=$ 'BARI Chinabadam-8'. Means were separated by Tukey's test at $\mathrm{P} \leq 0.05$. Vertical bars represent the standard error of the means.

observed from boron at 2-kg ha ${ }^{-1}$ compared to other treatments (Fig. 2), but control and $1-\mathrm{kg}$ boron ha-1 showed statistically similar resullts. The reason behind these findings might be that the number of pods and pod dry weight increased after the application of boron. Literature revealed that the reproductive development of groundnut can be influenced by boron, which significantly produced higher seed yield in groundnut (Jena et al., 2009), whereas 
harvest index might be higher in boron application area.

Therefore, light and born have a special importance on the vegetative growth and yield of groundnut, whereas both of the factors were highly responsible for the highest result of LAI, LAR, LMR and RWR. But in the case of RGR and NAR, an inconsistent result was found between the boron and light treatment.

\section{Conclusions}

In conclusion, boron application in groundnut field had a significantly positive impact that helped to produce higher physiological growth and yield of groundnut. But, due to the imposition of artificial light, it had both positive and negative effect on the physiological growth, whereas light reduced the seed yield. Thus, it is recommended to use boron, but not impose light, to get a better yield of groundnut. Boron helped to increase the physiological growth, pollen grain viability and stigma receptivity. That ultimately increased the number of pods, as well as pod yield. Supplementation of light increased the physiological growth and the number of flowers of groundnut. Therefore, light could increase the pod yield, but the duration of light was not enough for partitioning of dry matter towards the reproductive unit.

\section{Acknowledgements}

The authors humbly acknowledge the role of Shabiha Sultana, Deputy Director (Budget), Sher-e-Bangla Agricultural University, Dhaka-1207, Bangladesh, for awarding financial help and moral support. Thanks are also to Ministry of Science and Technology, Government of the People's Republic of Bangladesh sanctioning scholarship of the National Science and Technology (NST) fellowship for this study.

\section{References}

Acock MC, Lydon J, Johnson E, Collins R (1996). Effects of temperature and light levels on leaf yield and cocaine content in two Erythroxylum species. Annals of Botany 78(1):49-53.

Ahmed S, Hossain MB (1997). The problem of boron deficiency in crop production in Bangladesh. Boron in soils and plants. Kluwer Academic Publishers, Springer Netherlands 76:1-5.

Ansari MA, Prakash N, Singh IM, Sharma PK, Punitha P (2013). Efficacy of boron sources on productivity, profitability and energy use efficiency of groundnut (Arachis hypogaea) under North East Hill Regions. Indian Journal of Agricultural Sciences 83(9):959-963.

Bagnall DJ, King RW (1991). Response of peanut (Arachis hypogea) to temperature, photoperiod and irradiance 2. Effect on peg and pod development. Field Crops Research 26(3):279-293.

Banik CN, Nath R, Chakraborty PK (2009). Effect of dates of sowing on growth and yield of groundnut crop. Journal of Crop and Weed 5(5):59-62.

BBS (Bangladesh Bureau of Statistics) (20142015). Annual Survey Report. Bangladesh Bureau of Statistics. Statistics Division. Government of the Peoples Republic of Bangladesh. Dhaka 37.

Çikili Y, Samet H, Dursun S (2015). Mutual effects of boron and zinc on peanut (Arachis hypogaea L.) growth and mineral nutrition. Communications in Soil Science and Plant Analysis 46(5):641-651.
Dell B, Huang L (1997). Physiological response of plants to low boron. Plant soil 193(1-2):103-120.

El-Wahab A, Mohamed A (2008). Effect of some trace elements on growth, yield and chemical constituents of Trachyspermum amm $\mathrm{L}$. plants under Sinai conditions. Research Journal of Agriculture and Biological Sciences 4(6):717-724.

Gascho GJ, Davis JG (1995). Soil fertility and plant nutrition. In Pattee HE, Stalker HT (Eds). Advances in Peanut Science. Stillwater: American Peanut Research Education Society pp 383-418.

Geethanjali K, Ashoka RY, Narasimha RKL, Madhuvani P (2015). Effect of foliar application of ethrel and boron on morphological parameters, growth characteristics and yield in groundnut (Arachis hypogaea L.). International Journal of Food, Agriculture and Veterinary Sciences 5(1):120-125.

Hangarter RP (1997). Gravity, light and plant form. Plant, Cell \& Environment 20(6):796-800.

Harris HC, Brolman JB (1966). Comparison of calcium and boron deficiencies of peanut I. Physiological and Yield Differences. Agronomy Journal 58(6):575-578.

Jena D, Nayak SC, Mohanty B, Jena B, Mukhi SK (2009). Effect of boron and boron enriched organic manure on yield and quality of groundnut in boron deficient Alfisol. Environment and Ecology 27(2):685-688.

Mengel M, Kirkby EA (1982). Principles of plant nutrition, 3rd ed. International Potash Institute Bern Switzerland pp 125.

Kabir R, Yeasmin S, Islam AM, Sarkar MAR (2013). Effect of Phosphorus, Calcium and Boron on the growth and yield of groundnut (Arachis hypogea L.). International Journal of BioScience and Bio-Technology 5(3):51-60.

Ketring DL (1979). Light effects on development of an indeterminate plant. Plant Physiology 64(4):665-667.

Naiknware MD, Pawar GR, Murumkar SB (2015). Effect of varying levels of boron and sulphur on growth, yield and quality of summer groundnut (Arachis hypogea L.). International Journal of Tropical Agricultural 33.2(Part I)):471-474.

Nasreen S, Siddiky MA, Ahmed R, Rannu RP (2015). Yield response of summer country bean to boron and molybdenum fertilizer. Bangladesh Journal of Agricultural Research 40(1):71-76.

Nigam SN, NageswaraRao RC, Wynne JC (1998). Effects of temperature and photoperiod on vegetative and reproductive growth of groundnut (Arachis hypogaea L.). Journal of Agronomy and Crop Science 181(2):117-124.

Nigam SN, Rao RN, Wynne JC, Williams JH, Fitzner M, Nagabhushanam GVS (1994). Effect and interaction of temperature and photoperiod on growth and partitioning in three groundnuts (Arachis hypogaea L.) genotypes1. Annals of Applied Biology 125(3):541-552.

Onemli F (2012). Impact of climate change on oil fatty acid composition of peanut (Arachis hypogaea L.) in three market classes. Chilean Journal of Agricultural Research 72(4):483-488.

Prieto M, Peñalosa J, Sarro MJ, Zornoza P, Gárate A (2007). Seasonal effect on growth parameters and macronutrient use of sweet pepper. Journal of Plant Nutrition 30:1803-1820. 
Quamruzzaman M, Ullah MJ, Karim MF, Islam N, Rahman MJ, Sarkar MD (2016a). Response of boron and light on morphphysiology and pod yield of two peanut varieties. International Journal of Agronomy 2016:01-09.

Quamruzzaman M, Ullah MJ, Rahman MJ, Chakraborty R, Rahman MM, Rasul MG (2016b). Organoleptic assessment of groundnut (Arachis hypogaea L.) as influenced by boron and artificial lightening at night. World Journal of Agricultural Sciences 12(1):1-6.

Singaravel R, Parasath V, Elayaraja D (2006). Effect of organics and micronutrients on the growth, yield of groundnut in coastal soil. International Journal of Agriculture Sciences 2(2):401-402.
Tahir M, Tanveer A, Shah TH, Fiaz N, Wasaya A (2009). Yield response of wheat (Triticum aestivum $\mathrm{L}$.) to boron application at different growth stages. Pakistan Journal of Life and Social Sciences $7(1): 39-42$.

Tukey JW (1977). Exploratory data analysis. Reading PA: AddisonWesley.

Watson DJ, Wilson JH (1956). An analysis of the effects of infection with leaf-roll virus on the growth and yield of potato plants, and of its interactions with nutrient supply and shading. Annals of Applied Biology 44(3):390-409. 